Cultural Theory and the Problem of Modernity 
Also by Alan Swingewood

A SHORT HISTORY OF SOCIOLOGICAL THOUGHT

SOCIOLOGICAL POETICS AND AESTHETIC THEORY

THE MYTH OF MASS CULTURE 


\section{Cultural Theory and the Problem of Modernity}

Alan Swingewood

Macmillan Education 
ISBN 978-0-333-61342-9

ISBN 978-1-349-26830-6 (eBook)

DOI 10.1007/978-1-349-26830-6

CULTURAL THEORY AND THE PROBLEM OF MODERNITY

Copyright $\odot 1998$ by Alan Swingewood

Softcover reprint of the hardcover 1st edition 1998 978-0-333-61341-2

All rights reserved. No part of this book may be used or reproduced in any manner whatsoever without written permission except in the case of brief quotations embodied in critical articles or reviews.

For information, address:

St. Martin's Press, Scholarly and Reference Division, 175 Fifth Avenue, New York, N.Y. 10010

First published in the United States of America in 1998

This book is printed on paper suitable for recycling and made from fully managed and sustained forest sources.

ISBN 978-0-312-21508-8 clothbound

ISBN 978-0-312-21509-5 paperback

Library of Congress Cataloging-in-Publication Data

Swingewood, Alan.

Cultural theory and the problem of modernity / Alan Swingewood.

p. $\mathrm{cm}$.

Includes bibliographical references and index.

ISBN 978-0-312-21508-8 (cloth). - ISBN 978-0-312-21509-5 (pbk.)

1. Culture. 2. Culture-Philosophy. 3. Postmodernism.

I. Title.

HM101.S955 1998

$301-\mathrm{dc} 21$

98-13925

CIP 


\section{Contents}

Introduction ix

1 Theorising Culture: Marxism 1

Marx: Culture and Economic Production 3

Marxist Critiques of the Base-Superstructure Model 8

Gramsci: The Autonomy of Culture 13

2 Theorising Culture: Weber, Simmel and Social Action 22

Introduction 22

Rationality and the Sociology of Culture: Weber 23

Culture and the Principle of Autonomy 27

Simmel: Modernity and the Tragedy of Culture 30

The Culture of Modernity 32

3 Problems of Culture Industry 37

The Dialectic of Culture 40

Culture Industry and the Case of Music 44

Culture, Class and Critique 47

The Problem of Method: Culture Industry and Cultural Memory 48

4 Cultural Analysis and Systems Theory 53

The Concept of a Common Culture: From Durkheim to Parsons 53

Common Culture: Parsons $\quad 56$

Habermas: Culture and Communicative Practice 62

Culture and Interaction $\quad 67$ 
5 Contextualising Culture $\quad 70$

Context and Culture $\quad 70$

Contextualising Music: The Problem of Mediation 72

Cultural Materialism $\quad 74$

Culture as Ordinary: The Problem of a Common Culture $\quad 76$

The Structure of Feelings: Problems of Contextualisation $\quad 80$

6 The Theory of Cultural Fields $\mathbf{8 6}$

Structuralism and the Concept of System 86

Cultural Theory and the Short-Circuit Effect 88

Cultural Sociology and the Concept of Field 92

Habitus, Practices and the Cultural Fields 94

The Concept of Force Field 99

Limitations of Field Theory 103

7 Dialogism and Cultural Forms 108

Cultural Fields: Agency and Communication 108

Bakhtin: Culture, Self and Dialogue 113

Discourse, Language and Culture 117

Unofficial Culture: The Concept of the Carnivalesque 126

Dialogism, Enclosure and Historical Context:

The Case of the Novel 130

8 Modernity and Culture 136

What is Modernity? 136

Modernity 1: From Baudelaire to Foucault 141

Excursus: Modernity as Newness in the Present Foucault on Baudelaire $\quad 142$

Simmel's Modernity 144

Modernity 2: Critique of Enlightenment From Weber to the Frankfurt School 146

Theorising Modernity: The Frankfurt School 149

Modernity 3: Marx 153

9 Postmodernity and Mass Culture 159

Critique of Modernity 1: The Postmodern and the Grand Narrative 159

Critique of Modernity 2: Postmodernism and Culture 161

Postmodernism, Mass Culture and the Logic of Capitalism 166

Concluding Remarks: The Problem of Modernity, History and Postmodernism 
Contents

vii

Conclusion

Bibliography

Index
174

181

186 


\section{Introduction}

The 1980s and 1990s have witnessed an explosion of interest in the study of culture. If alienation, ideology and hegemony had been the key words of earlier periods, culture was now the dominant concern for the humanities and social sciences. Although it had always occupied an important place within the various humanist disciplines, culture had tended to become assimilated to literary and aesthetic analysis (culture forming a background and context) or to the study of social structure, social institutions and social change (culture as socialisation). As for Marxism, one of the major intellectual currents of the post-war years, culture came to enjoy a shadowy presence and problematic status frequently identified as a form of ideology and analysed as a reflection of specific class and political interests yet signifying a critical realm of human values and aspirations. What was common to Marxist, literary and social studies, however, was a failure to adequately theorise culture and develop specific concepts for the analysis of its internal properties, the variety of its forms and links with human activity and the complex, highly differentiated structures of modern society. The rise of cultural studies during the 1960s (in the widely different work of Richard Hoggart, E. P. Thompson and Stuart Hall, with its institutional setting the Centre for Contemporary Cultural Studies at the University of Birmingham) had emphasised the social aspects of culture (it was not simply about art and literature but concerned with communication and community) without generating a necessary sociological framework and conceptual tools. The breakup of cultural studies into specialist areas of media, feminism and 
ethnicity, a process influenced by new, largely European theories of politics, ideology, discourse and the subject, further shifted the study of culture away from sociology.

However, one result of these developments was to broaden the definition of culture away from its narrow identification with literature and art to include fashion and food, sport and advertising, journalism and everyday life, as well as working-class subcultures characterised by various forms of ritual and resistence to the dominant social values. As E. P. Thompson has pointed out, culture is

a clumpish term which by gathering up so many activities and attributes into one common bundle may actually confuse or disguise discriminations... We need to take this bundle apart and examine the components with more care: rites, symbolic modes, the cultural attributes of hegemony, the inter-generational transmission of custom and custom's evolution within historically specific forms of working and social relations. (Thompson, 1993, p.13)

In this book I attempt to unravel the various meanings of culture and develop a distinctive sociological approach, to theorise culture sociologically. For while culture has become critical for contemporary studies, its meaning has been influenced by a bewildering range of theoretical frameworks and theorists (such as those of Althusser, Foucault and Baudrillard) in which linguistic and discourse analysis together with postmodernism advance concepts and methods alien to the sociological study of culture. Historically the study of culture as a separate and distinct realm, with its own specific internal properties, was closely linked to philosophy and anthropology. At the end of the eighteenth century culture was largely identified with the idea of civilisation, with holisitic concepts such as a world view or 'mentality'. Williams notes its original meaning as 'to cultivate', the tending of natural growth as in agriculture, but by 1800 the word signalled the transition from nascent industrialism to capitalism and modernity. In the course of the nineteenth century culture increasingly became intellectualised, identified with habits of mind and humane values, defined idealistically in terms of the arts and 'high' rather than 'low' or 'ordinary' culture. In England culture constituted an aesthetic and literary discourse centred on the perfection of humanity, the creation of universal values, 'sweetness and light' in opposition to a dehumanising and ugly machine civilisation. In the works of Matthew Arnold 
(1822-88) culture is defined as a body of creative work (literary texts) which embodies high moral values, a rejection of industrialism, materialism and philistinism. Culture is social in so far as it affirms a civilising mission, although narrowly conceived in terms of texts which generate binary divisions such as high versus low. This culture and society tradition becomes further developed in the work of F. R. Leavis, T. S. Eliot and Raymond Williams, the first-named forging a contrast between pre-industrial culture (which hecalled 'organic' and community-based) with twentieth-century industrial, capitalist mass culture built around atomistic social relations. In an important sense the literary critic Leavis and the poet and critic Eliot were largely responsible for socially contextualising culture and initiating the debate on mass culture, popular culture and minority culture in English literary studies. I examine this approach in Chapter 5, arguing that this idealist notion of culture, while bound up with high art forms, is nevertheless based in the idea of community and social experience. Culture is a whole way of life embracing texts and community values, in Eliot's words, 'the characteristic activities and interests of a people'. Culture was normative, critical of industrialism, affirming tradition, universal values and a sense of historical continuity.

In a similiar vein, Williams defines culture holistically as a whole way of life, as ordinary and more closely linked with everyday life than in the Leavis-Eliot model. In effect, Williams seeks to unify the literary approach to culture with the anthropological. It was E. B. Tylor who argued that all societies, of every type and at all stages of social development possess a culture. Culture is not coterminous with civilisation but constitutes 'that complex whole which includes knowledge, belief, art, morals, law custom and other capabilities acquired by man as a member of society' (Tylor, 1958, p. 1). Through values and symbols, individuals are able to communicate and form communities within the whole. Early anthropological approaches to culture tended to adopt a functionalist standpoint, values and symbols working to promote social cohesion. But one of the main problems with such holistic notions is their relevance to modern complex, highly differentiated societies, with their multiple social groups and classes. In modern society there exist many different ways of life bound up with issues of ideology and power, with complex patterns of social conflict and social struggles. There is, too, the question of meaning and action: Tylor's definition of culture conceives 
it in material not idealistic terms without raising the problem of its making.

Contemporary anthropological approaches to studying culture have sought to modify this excess of materialism by arguing that culture involves 'an historically transmitted pattern of meanings embodied in symbols, a system of inherited conceptions expressed in symbolic forms by means of which men communicate, perpetuate, and develop their knowledge about and attitude toward life' (Geertz, 1973, p. 89). Clifford Geertz's more subtle concept of culture has been widely influential, especially in those sociological approaches to cultural analysis which focus on beliefs, values and symbols as the constituent elements of culture.

Distinguishing anthropological from sociological concepts of culture is difficult if a purely internal approach is adopted. In this book I am concerned both with the sociology of culture and the relation of culture to modernity. As I argue in Chapter 8, sociology is closely related to the project of modernity, to the development of highly differentiated societies which provide the institutional basis for the autonomy of culture and a reflexive individual. Culture, in other words, is about norms, values and symbols but, as Geertz noted, it is equally about meaning and action. A sociological perspective is one which locates culture in terms of its social basis, in modernity, and the complex meanings it both embodies and generates through social action.

But I think it needs emphasising that the boundaries between sociological and anthropological concepts of culture are fluid and frequently overlap. Durkheim, for example, in his study of early religion in pre-modern societies (notably the Australian aborigines) analyses culture sociologically, as a signifying system that produces collective representations (totems for example) through which individuals develop a sense of identity with the whole society. Collective representations are one of the means whereby society achieves integration, but the point is that Durkheim's approach to culture emphasises the meanings which symbols have for individual members. Equally, Weber defined culture as the realm of meaning which constituted the basis of social action and social change. In Chapters 2 and 4, Weber's and Durkheim's theories of culture are examined, Weber advancing the important concept of the 'relative autonomy' of culture, culture as values, symbols and practices which, in the period of 
modernity, possess their own distinctive logic and structure. Durkheim, too, with his notion of culture as collective representations, seeks to establish a partly autonomous cultural realm. It is this aspect of culture which is further developed in interactionist sociology, especially in Goffman's work on the interaction order in which specific symbolic forms based on ritual and shared meaning enable individuals to produce a complex notion of self.

In contrast, functionalist approaches to culture analyse symbolic forms (ritual, myth and codes) for the ways they maintain social order and integration, assimilating meaning to the process of socialisation and effectively marginalising the active role of human agents in the production of culture. As I argue in Chapter 1, some versions of Marxism adopt this functionalist perspective, theorising culture as ideology, as a reflex of external material conditions and an expression of class interests: culture as social cement binding individuals collectively to the core values of capitalism. However, this reductive notion has been challenged by culturalist Marxists as Gramsci, Adorno and Bakhtin. Chapters 1 and 3 address the problem of culture conceived in its integral relation with social struggles and power relations, practices and meaning. Culture is less a way of life than sites of struggle imbricated in ideology and politics, overlaid with issues of gender, race and generation. Culture is not the expression or the representation of class, but the active articulation of complex identity.

Culture, then, is the realm of meaning, of values and symbols, located in specific structural contexts. The problem of contextualism is one of the most critical issues of cultural theory, that as culture is produced within contexts it must never be reduced to context. In Chapter 6 I examine one recent sociological theory of context, Bourdieu's concept of field, and the attempt to integrate the principle of partial autonomy of culture with capitalist industrialisation and social change. Bourdieu's concept of culture, like that of Gramsci, links it with social struggle and an open rather than closed notion of society. For while culture is concerned with meaning it is not a fixed and completed meaning, since while bound to context, culture goes beyond it by affirming the irreducible pluralism of social life. One of the major themes of the sociology of culture, from Parsons to Gramsci, the Frankfurt School, Weber and Durkheim to Bourdieu and Bakhtin, is that culture generates universal elements that in some way transcend historical contexts. Chapter 7 explores Bakhtin's 
historical sociology of culture and its attempt to develop a concept of culture which is the product not simply of social struggle but of dialogue between different voices and standpoints: Bakhtin's dialogic principle is one that suggests culture as the realm of open, unfinished and multiple meanings.

Raymond Williams has noted that cultural sociology was a 'late entry' into sociology 'after the hard stuff of class, industry and politics', with its development 'little more than a loose grouping of specialist studies either of communications...the media or ...the arts' (Williams, 1981, p. 9). A new kind of sociology is now required to deal with culture: this book is an attempt to engage with this problem. 